\title{
Detection of variants in the mitochondrial glycerophosphate dehydrogenase gene in Japanese NIDDM patients
}

\author{
Y.Takeuchi, A . M atsutani, Y. 0 ka \\ Third Department of Internal Medicine, Yamaguchi University School of Medicine, Yamaguchi, Japan
}

Summary Mitochondrial FAD-linked glycerophosphate dehydrogenase (mGPDH) is thought to be an important factor for glucose sensing in pancreatic beta cells. To evaluate the significance of the mGPDH gene in the development of non-insulin-dependent diabetes mellitus (NIDDM), we set up primers and conditions for polymerase chain reaction (PCR) amplification of the coding exons and flanking regions. Screening of 100 Japanese NIDDM patients for mutations using the PCR-single strand conformation polymorphism (SSCP) method revealed four variants (ACA:Thr243-ACG:Thr243, CAT:His264CGT:Arg264, GCA:Ala305-GCC:Ala305, GCA:Ala 306-TCA:Ser306). The His264-Arg264 variant was found in 36 patients, while the other variants were found in only one patient each. Neither the genotypic $\left(\chi^{2}=3.15, p=0.21\right)$ nor the allelic $\left(\chi^{2}=2.27, p=0.13\right)$ frequency of the His264-Arg264 mutation differed between 253 Japanese NIDDM patients and 157 non-diabetic subjects. In addition, in NIDDM patients, neither the treatment modality nor body mass index differed between those with and without this mutation. These results suggest that inherited defects at this locus do not make a major contribution to genetic susceptibility to NIDDM in the Japanese population. [Diabetologia (1997) 40: 339-343]

Keywords mGPDH gene, amino acid variants, NIDDM, PCR-SSCP, beta cells.
Genetic factors play an important role in the development of non-insulin-dependent diabetes mellitus (NIDDM), which is characterized by both decreased insulin secretion and insulin resistance. Recent advances in molecular biology and molecular genetics provide opportunities to analyse candidate genes for the development of NIDDM in several ways such as population association studies $[1,2]$, linkage analysis in families with NIDDM or direct detection of gene

Received: 14 August 1996 and in revised form: 5December 1996

Corresponding author: A. Matsutani, M. D., Third Department of Internal Medicine, Yamaguchi University School of Medicine, 1144 Kogushi, Ube, Yamaguchi 755, Japan

A bbreviations: PCR-SSCP, Polymerase chain reaction-single strand conformation polymorphism; NIDDM, non-insulin-dependent diabetes mellitus; MODY, maturity onset diabetes of the young; mGPDH, mitochondrial FAD-linked glycerophosphate dehydrogenase. variations using the polymerase chain reaction-single strand conformation polymorphism (PCR-SSCP) method in affected subjects [3,4]. Recent demonstrations that mutations of the glucokinase gene [5-7] and mitochondrial DNA [8-10] cause diabetes with insulin-secretion defects prompted us to search for other genetic anomalies possibly contributing to the impaired insulin secretion in NIDDM patients.

Glucose is the most important and potent physiological stimulus for insulin secretion, and pancreatic beta cells have unique metabolic mechanisms allowing utilization of this nutrient. The GLUT2 glucose transporter [11, 12] and glucokinase [13, 14] are among these mechanisms. These molecules are believed to constitute a glucose sensor [13], and the higher $\mathrm{K}_{\mathrm{m}}$ of glucokinase and GLUT2 for glucose, as compared with other isoforms, might be essential for pancreatic beta cells to alter insulin secretion in response to changes in blood glucose levels within the physiological range. Further evidence to support the 
importance of glucokinase in pancreatic beta-cell function has been provided by studies showing that genetic defects of this molecule can cause NIDDM by raising the set point for glucose triggering of insulin secretion from pancreatic beta cells in MODY (maturity-onset diabetes of the young) families [15]. Thus, proteins or systems participating in glucose metabolism in pancreatic beta cells, which are uniquely or abundantly expressed in these cells, could be key components of the glucose-induced insulin secretion mechanism.

One such candidate protein is mitochondrial FAD-linked glycerophosphate dehydrogenase (mGPDH). This enzyme catalyses the conversion of glycerol 3-phosphate to dihydroxyacetone phosphate to produce $\mathrm{FADH}_{2}$ from FAD [16]. This reaction is generally thought to be a rate-limiting step, although controversy persists [17-19], in the glycerol phosphate shuttle which transfers cytosolic reducing equivalents to the mitochondrial electron transport chain. Although mGPDH is expressed in essentially all tissues, it is especially abundant in brain, skeletal muscle, and pancreatic islets [20] which require rapid glucose oxidation. Moreover, recent evidence suggests the involvement of $\mathrm{mGPDH}$ in pancreatic beta-cell glucose sensing [21, 22], and decreased mGPDH activity has been reported in the pancreatic islets of animal models of NIDDM [23-25] and in NIDDM patients [26]. Rat [27, 28] and human [2931] mGPDH cDNAs have been cloned and we recently cloned the human genomic gene for mGPDH and determined its exon-intron organization [32].

In the present study, to test the hypothesis that defects of the mGPDH gene contribute to susceptibility to NIDDM, we determined primers and conditions for PCR amplification of exons and screened Japanese subjects for mutations in coding regions of the mGPDH gene by the PCR-SSCP method.

\section{Subjects and methods}

Subjects. One hundred NIDDM patients were analysed for mGPDH gene variations. The frequency of the His264-Arg264 variation was compared between 253 NIDDM patients (146 men and 107 women, $58.3 \pm 10.9$ years of age, BMI $22.9 \pm 3.1 \mathrm{~kg} / \mathrm{m}^{2}$ [mean $\left.\left.\pm \mathrm{SD}\right]\right)$ and 157 non-diabetic subjects (59 men and 98 women, $62.1 \pm 15.3$ years of age, BMI $21.7 \pm 3.2 \mathrm{~kg} / \mathrm{m}^{2}$ ). All subjects were unrelated Japanese over the age of 40 years who had been randomly recruited from the outpatient clinics at Yamaguchi University Hospital and affiliated hospitals. Individuals with NIDDM met the diagnostic criteria of the World Health Organization. Family history was positive in 113 of the 253 NIDDM patients. Fifty-four patients were treated with insulin, 77 with sulphonylureas and 122 with diet therapy only. Non-diabetic subjects had a random plasma glucose level of less than $6.7 \mathrm{mmol} / \mathrm{l}$, a normal $\mathrm{HbA}_{1 \mathrm{C}}$ level and no personal or family history of diabetes. Informed consent was obtained according to the protocol approved by the Human Studies Committee of Yamaguchi University Hospital.
PCR-SSCP analysis of the coding exons of the MGPDH gene. The upstream and downstream sequences of each exon of the human mGPDH gene were determined based on the previously described exon-intron organization [32]. Fifteen sets of primers designed to flank the coding exons were synthesized using a DNA synthesizer (Model 392; Applied Biosystems Japan, Urayasu, Japan). The primers were designed using introns other than the antisense primer for exon 16, because exon 16 was found to contain a large non-coding region. Primer sequences, product size and Ta are listed in Table 1.

PCR was performed in $10 \mu \mathrm{l}$ of a reaction mixture containing $100 \mathrm{ng}$ genomic DNA, 2 pmol each of the sense and antisense primers, $0.1 \mathrm{mmol} / \mathrm{l} \mathrm{dNTP}, 10 \mathrm{mmol} / \mathrm{l}$ Tris- $\mathrm{HCl}(\mathrm{pH} 8.3)$, $50 \mathrm{mmol} / \mathrm{l} \mathrm{KCl}, 2 \mathrm{mmol} / 1 \mathrm{MgCl}_{2}, 0.01 \%$ gelatin, 0.25 units AmpliTaq DNA polymerase and $0.67 \mu \mathrm{Ci}$ of $\alpha-\left[{ }^{32} \mathrm{P}\right] \mathrm{dCTP}$ (Amersham, Tokyo, Japan). After the initial denaturation at $94^{\circ} \mathrm{C}, 30$ cycles of amplification were performed with denaturation at $94^{\circ} \mathrm{C}$ for $1 \mathrm{~min}$, annealing for $1 \mathrm{~min}$ at the temperature indicated in Table 1 , and extension at $72^{\circ} \mathrm{C}$ for $1 \mathrm{~min}$, followed by a final extension at $72^{\circ} \mathrm{C}$ for $10 \mathrm{~min}$.

SSCP was conducted essentially according to the method described by Orita et al. [33]. Ten microlitres of the PCR product was mixed with $30 \mu \mathrm{l}$ of $95 \%$ formamide, $20 \mathrm{mmol} / \mathrm{l}$ EDTA, $0.05 \%$ bromophenol blue and xylene cyanol. Samples were heat-denatured at $94^{\circ} \mathrm{C}$ for $3 \mathrm{~min}$ and then electrophoresed under two different conditions: 1) $5 \%$ polyacrylamide (49:1, acrylamide: $\mathrm{N}, \mathrm{N}^{\prime}$-methylene-bis-acrylamide) gel in $1 \times \mathrm{TBE}(90 \mathrm{mmol} / 1$ Tris-borate $\mathrm{pH} 8.3,2 \mathrm{mmol} / \mathrm{l}$ EDTA) at $30 \mathrm{~W}$ for $4-5 \mathrm{~h}$, and 2) $5 \%$ polyacrylamide gel in $1 \times \mathrm{TBE}$ with $5 \%$ glycerol at $10 \mathrm{~W}$ for $12-15 \mathrm{~h}$, both at room temperature. After electrophoresis, gels were dried and exposed to $\mathrm{X}$ ray film with an intensifying screen for $10-24 \mathrm{~h}$ at $-80^{\circ} \mathrm{C}$. Genotyping of NIDDM patients and non-diabetic subjects for the variants were essentially performed by the PCR-SSCP method described above.

DNA sequencing. PCR was performed under the same conditions as described above except for omission of $\alpha-\left[{ }^{32} \mathrm{P}\right] \mathrm{dCTP}$. DNA fragments were electrophoresed on $1 \%$ low-melting agarose (Cosmo Bio, Tokyo, Japan) gel, purified with a Wizard PCR Preps kit (Promega, Madison, Wis., USA), and sequenced using a Taq Dye Deoxy Terminator Cycle Sequencing Kit and model 373A DNA Sequencer (Perkin Elmer Japan, Urayasu, Japan). When the results obtained by direct sequencing were ambiguous, PCR products were ligated to pTBlue Vector (Novaegen, Madison, Wis., USA) and the cloned DNA was sequenced.

Statistical analysis. The statistical significance of differences in quantitative variables between groups was analysed using the unpaired t-test. Associations between the amino acid variations and NIDDM were examined using the chi-square test.

\section{Results}

Variations in the mGPDH gene. All coding exons of the human mGPDH gene, designated exons 1 to 16 in this study, were amplified using the primers and conditions described in Table 1. A total of three variant electrophoretic patterns were detected in exon 6 and exon 7, by PCR-SSCP analysis, in 100 Japanese NIDDM patients. DNA fragments with variable patterns were subsequently analysed by direct sequencing or sequencing of cloned DNA. Since one of three 
Table 1. Primer sets for PCR-SSCP analysis of human mGPDH gene

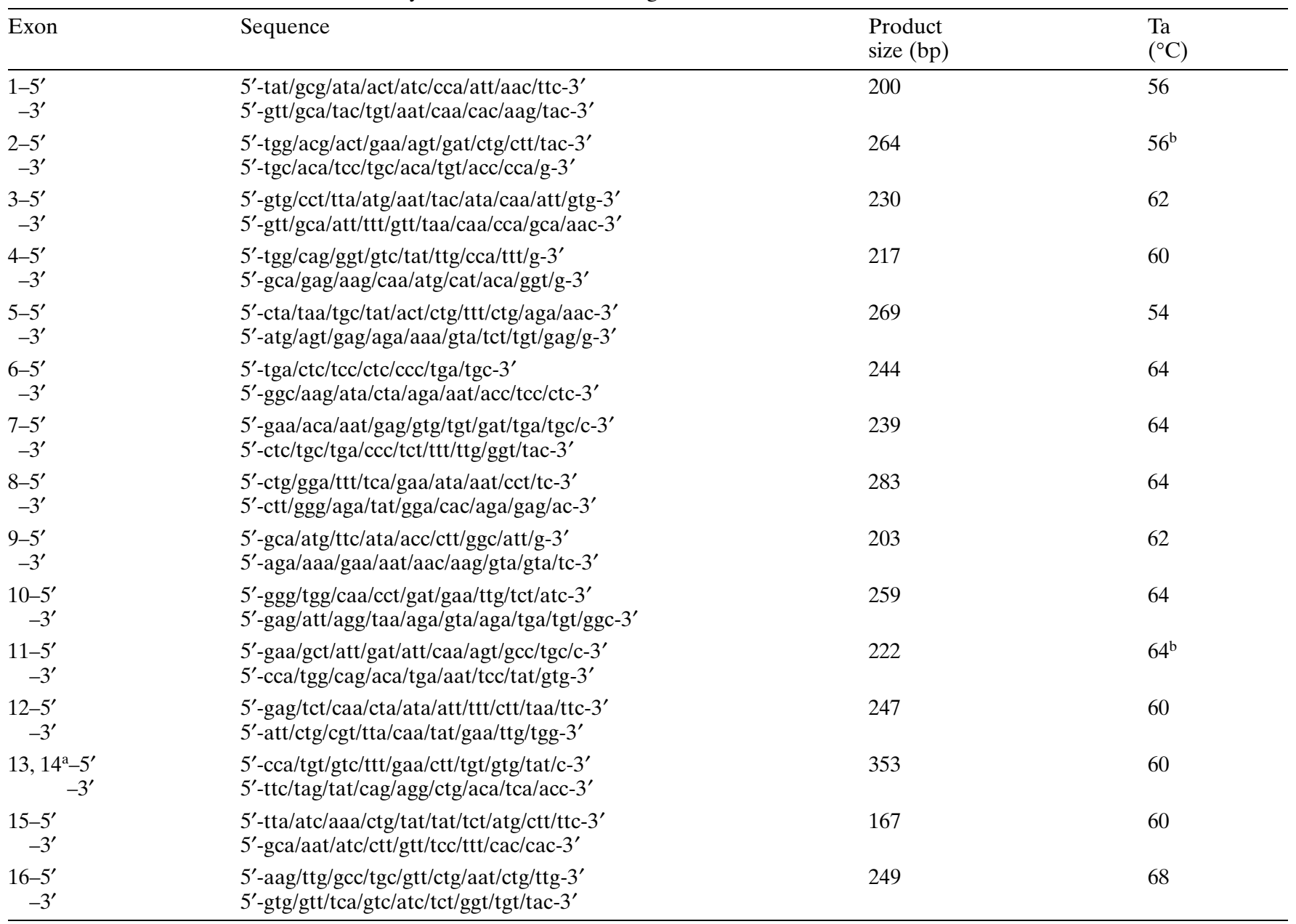

${ }^{a}$ Exons 13 and 14 amplified simultaneously;

b $10 \%$ glycerol added to the reaction mixture

variant electrophoretic patterns was ascribed to two successive sequence variants, a total of four sequence variants were identified. Characterization of the four variants, two silent and the other two missense, are summarized in Table 2. While one of the two missense mutations (His264-Arg264) does not result in a change in amino acid polarity, the other (Ala306Ser306) does change the polarity.

Frequency of $\mathrm{H}$ is264-A rg264 substitution in Japanese NIDDM and non-diabetic subjects. The 791 A-G transversion causing a His264-Arg264 amino acid substitution was frequently observed. The association of this mutation with NIDDM was examined by comparing its frequencies in NIDDM patients and nondiabetic subjects (Table 3). However, neither genotypic $\left(\chi^{2}=3.15, p=0.21\right)$ nor allelic $\left(\chi^{2}=2.27\right.$, $p=0.13)$ frequency differed between the two groups. We also investigated whether this mutation is associated with the clinical characteristics of Japanese NIDDM patients. However, neither treatment modality nor BMI differed significantly between patients with the Arg264 mutation and those without the mutation (data not shown).

\section{Discussion}

In this study, we determined primers and conditions for PCR amplification of all coding exons of human $\mathrm{mGPDH}$ and evaluated the significance of this gene as a possible factor in the genetic background of NIDDM. Screening using the PCR-SSCP method revealed four mutations in two exons. Two were silent mutations, while the other two caused amino acid substitutions potentially affecting enzymatic activity and thereby leading to beta-cell dysfunction, although the functional consequences of these two missense mutations have yet to be determined. The His264-Arg264 substitution is frequently observed in NIDDM patients, but the lack of a significant difference in either allelic or genotypic frequency between NIDDM and non-diabetic subjects suggests that this mutation does not make a major contribution to the 
Table 2. Characterization of variants on PCR-SSCP analysis

\begin{tabular}{llll}
\hline Exon & Nucleotide & Wild & Variant \\
\hline 6 & 729 & ACA(His243) & ACG(His243) \\
6 & 791 & CAT(His264) & CGT(Arg264) \\
7 & 915 & GCA(Ala305) & GCC(Ala305) \\
7 & 916 & GCA(Ala306) & TCA(Ser306) \\
\hline
\end{tabular}

Nucleotide number starts at the translation initiation site. $\mathrm{Mu}-$ tations in 915 and 916 are on a single allele of one patient

Table 3. Frequency of Arg264 in Japanese NIDDM patients and non-diabetic subjects

\begin{tabular}{|c|c|c|c|c|}
\hline & \multicolumn{4}{|c|}{$\begin{array}{l}\text { Allelic frequency } \\
\text { Number (frequency) }\end{array}$} \\
\hline & \multicolumn{2}{|l|}{ His } & \multicolumn{2}{|l|}{ Arg } \\
\hline NIDDM & \multicolumn{2}{|l|}{$394(0.78)$} & $112(0.22)$ & 506 \\
\hline Non-diabetic & \multicolumn{2}{|l|}{$259(0.82)$} & $55(0.18)$ & 314 \\
\hline Total & \multicolumn{2}{|l|}{653} & 167 & 820 \\
\hline \multicolumn{5}{|c|}{$\chi^{2}=2.27, p=0.13$} \\
\hline & \multicolumn{4}{|c|}{$\begin{array}{l}\text { Genotypic frequency } \\
\text { Number (frequency) }\end{array}$} \\
\hline & His/His & His/Arg & Arg/Arg & \\
\hline NIDDM & $159(0.63)$ & $76(0.30)$ & $18(0.07)$ & 253 \\
\hline Non-diabetic & $107(0.68)$ & $45(0.29)$ & $5(0.03)$ & 157 \\
\hline Total & 266 & 121 & 23 & 410 \\
\hline
\end{tabular}

$\chi^{2}=3.15, p=0.21$

development of diabetes. It should also be noted that Arg264 appears to be evolutionally conserved, since this substitution is also found in the rat and mouse sequence. In contrast to the His264-Arg264 substitution being conservative in terms of amino acid polarity, the Ala306-Ser306 substitution causes a change in amino acid polarity and was found only in the NIDDM group. Furthermore, Ser306 is not found in the sequence of rat or mouse mGPDH. The possible role of this mutation in the development of NIDDM awaits further investigation.

Defects of mGPDH have the potential to impair ATP production in pancreatic beta cells, thereby decreasing glucose-induced insulin secretion. However, the activity of this enzyme was reported to be decreased only in the pancreas, not in the liver, in animal models with NIDDM $[23,25]$. These results may suggest that defects in the regulatory region, rather than coding regions, of the gene are responsible for the development of NIDDM in humans. Alternative splicing of untranslated regions of the mGPDH gene has also been suggested [31]. The promoter and other regulatory elements of the gene require further characterization.

The lack of linkage to the mGPDH locus was shown in three MODY families, based on simple tandem repeat polymorphism [34]. The same authors demonstrated, in a population association study, that NIDDM is not associated with this locus. The results of the present study also point away from a major role for the mGPDH gene in the development of NIDDM. However, the possibility of minor involvement of this gene in the development of NIDDM cannot be ruled out, because homozygosity of Arg264 was more frequent in the NIDDM group (7\%) than in the non-diabetic group (3\%) in this study, although the difference was not statistically significant. Further accumulation of cases for analysis and correlation of the missense mutation with more sensitive clinical characteristics, representing insulin-secretion defects, are needed. It is also necessary to examine the effects of mGPDH variations, when expressed in cells, on enzymatic activity and insulin secretion.

A cknowledgements. This study was supported by a Grant-in Aid for Scientific Research (C) 06671034 (A.M.) and a Grant-in Aid for Developmental Scientific Research (B) 06557056 (Y.O.) from the Ministry of Education, Science, Sports and Culture of Japan. The skilful laboratory assistance of Ms. Y.Kohra-Miura and K. Ushio is gratefully acknowledged.

\section{References}

1. Matsutani A, Kolanyi L, Cox N, Permutt MA (1990) Polymorphisms of GLUT2 and GLUT4 Genes. Diabetes 39: 1534-1542

2. Noda K, Matsutani A, Tanizawa Y et al. (1993) Polymorphic microsatellite repeat markers at the glucokinase gene locus are positively associated with non-insulin dependent diabetes mellitus in Japanese. Diabetes 42: 1147-1152

3. Tao T, Tanizawa Y, Matsutani A, Matsubara A, Kaneko T, Kaku K (1995) HepG2/erythrocyte glucose transporter (GLUT1) gene in NIDDM: a population association study and molecular scanning in Japanese subjects. Diabetologia 38: 942-947

4. Matsubara A, Tanizawa Y, Matsutani A, Kaneko T, Kaku K (1995) Sequence variations of the pancreatic islet/liver glucose transporter (GLUT2) gene in Japanese subjects with non-insulin-dependent diabetes mellitus. J Clin Endocrinol Metab 80: 3131-3135

5. Froguel P, Zouali H, Vionnet N et al. (1993) Familial hyperglycemia due to mutations in glucokinase. Definition of a subset of diabetes mellitus. N Engl J Med 328: 697-702

6. Katagiri H, Asano T, Ishihara H et al. (1992) Nonsense mutation of glucokinase gene in late-onset non-insulin-dependent diabetes mellitus. Lancet 340: 1316-1317

7. Shimada F, Makino H, Hashimoto N et al. (1993) Type 2 (non-insulin-dependent) diabetes mellitus associated with a mutation of the glucokinase gene in a Japanese family. Diabetologia 36: 433-437

8. Ballinger SW, Shoffner JM, Hedaya EV et al. (1992) Maternally transmitted diabetes and deafness associated with a $10.4 \mathrm{~kb}$ mitochondrial DNA deletion. Nature Genetics 1: $11-15$

9. Oka Y, Katagiri H, Yazaki Y, Murase T, Kobayashi T (1993) Mitochondrial gene mutation in islet-cell-antibodypositive patients who were initially non-insulin-dependent diabetics. Lancet 342: 527-528

10. Kadowaki T, Kadowaki H, Mori Y et al. (1994) A subtype of diabetes mellitus associated with the mutation at 
position 3243 of the mitochondrial gene. N Engl J Med 330: 962-968

11. Thorens B, Sarkar HK, Kaback HR, Lodish HF (1988) Cloning and functional expression in bacteria of a novel glucose transporter present in liver, intestine, kidney and beta-pancreatic islet cells. Cell 55: 281-290

12. Orci L, Unger RH, Ravazzola M et al. (1990) Reduced beta-cell glucose transporter in new onset diabetic BB rats. J Clin Invest 86: 1615-1622

13. Matschinsky FM (1990) Glucokinase as glucose sensor and metabolic signal generator in pancreatic beta-cells and hepatocytes. Diabetes 39: 647-652

14. Meglasson MD, Matschinsky FM (1986) Pancreatic islet glucose metabolism and regulation of insulin secretion. Diabetes Metab Rev 2: 163-214

15. Velho G, Froguel Ph, Clement K et al. (1992) Primary pancreatic beta-cell secretory defect caused by mutations in glucokinase gene in kindreds of maturity onset diabetes of the young. Lancet 340: 444-448

16. Stryer L (1995) Biochemistry. 4th edn. WH Freeman, New York

17. Cederbaum AI, Lieber CS, Beattie DS, Rubin E (1973) Characterization of shuttle mechanisms for the transport of reducing equivalents into mitochondria. Arch Biochem Biophys 158: 763-781

18. Dionishi O, Cittadini A, Gelmuzzi G, Galeotti T, Terranova $\mathrm{T}$ (1970) The role of $\alpha$-glycerophosphate shuttle in the reoxidation of cytosolic NADH in Ehrlich ascites tumor cells. Biochim Biophys Acta 216: 71-79

19. Werner HV, Berry MN (1974) Stimulatory effects of thyroxine administration on reducing-equivalent transfer from substrate to oxygen during hepatic metabolism of sorbitol and glycerol. Eur J Bochem 42: 315-324

20. Sekine N, Cirulli V, Regazzi R et al. (1994) Low lactate dehydrogenase and high mitochondrial glycerol phosphate dehydrogenase in pancreatic b-cells. J Biol Chem 269: 4895-4902

21. MacDonald MJ (1990) Elusive proximal signals of betacells for insulin secretion. Diabetes 39: 1461-1466

22. MacDonald MJ (1981) High content of mitochondrial glycerol-3-phosphate dehydrogenase in pancreatic islets and its inhibition by diazoxide. J Biol Chem 256: 8287-8290

23. Giroix MH, Rasschaert J, Bailbe D et al. (1991) Impairment of glycerol phosphate shuttle in islets from rats with diabetes induced by neonatal streptozocin. Diabetes 40: 227-232
24. Rasschaert J, Malaisse-Lagae F, Sener A et al. (1994) Impaired FAD-glycerophosphate dehydrogenase activity in islet and liver homogenates of fa/fa rats. Mol Cell Biochem 135: 137-141

25. Ostenson CG, Abdel-Halim SM, Rasschaert J et al. (1993) Deficient activity of FAD-linked glycerophosphate dehydrogenase in islets of GK rats. Diabetologia 36: 722-726

26. Fernandez-Alvarez J, Conget I, Rasschaert J et al. (1994) Enzymatic, metabolic and secretory patterns in human islets of type 2 (non-insulin-dependent) diabetic patients. Diabetologia 37: 177-181

27. Muller S, Seitz HJ (1994) Cloning of a cDNA for the FADlinked glycerol-3-phosphate dehydrogenase from rat liver and its regulation by thyroid hormones. Proc Natl Acad Sci USA 91: 10581-10585

28. Brown LJ, MacDonald MJ, Lehn DA, Moran SM (1994) Sequence of rat mitochondrial glycerol-3-phosphate dehydrogenase cDNA. J Biol Chem 269: 14363-14366

29. Lehn DA, Brown LJ, Simonson GD, Moran SM, Mac Donald MJ (1994) The sequence of a human mitochondrial glycerol-3-phosphate dehydrogenase-encoding cDNA. Gene 150: 417-418

30. MacDonald MJ, Moran SM, Simonson GD (1995) The amino acid sequence of the pancreatic islet mitochondrial glycerol phosphate dehydrogenase is not unique and the enzyme is not thyroid or glucose responsive. Arch Biochem Biophys 319: 305-308

31. Ferrer G, Aoki M, Behn P, Nestorowicz A, Riggs A, Permutt MA (1996) Mitochondrial glycerol-3-phosphate dehydrogenase, cloning of an alternative spliced human isletcell cDNA, tissue distribution, physical mapping, and identification of a polymorphic genetic marker. Diabetes 45: 262-266

32. Matsutani A, Takeuchi Y, Ishihara H, Kuwano S, Oka Y (1996) Molecular cloning of human mitochondrial glycerophosphate dehydrogenase gene: genomic structure, chromosomal localization and existence of a pseudogene. Biochem Biophys Res Commun 223: 481-486

33. Orita M, Suzuki Y, Sekiya T, Hayashi K (1989) Rapid and sensitive detection of point mutation and DNA polymorphisms using the polymerase chain reaction. Genomics 5: 874-879

34. Warren-Perry MG, Stoffel M, Saker PJ et al. (1996) Mitochondrial FAD-glycerophosphate dehydrogenase and Gprotein-coupled inward rectifying $\mathrm{K}^{+}$channel. No evidence for linkage in maturity-onset diabetes of the young or NIDDM. Diabetes 45: 639-641 